\title{
The influence of labor and land use management on rice farming production in Pohuwato District
}

\author{
Syarwani Canon; Amir Halid; Fanny Daud \\ Agribusiness Study Department, Post Graduated Program, Universitas Negeri Gorontalo, \\ Indonesia \\ e-mail correspondence: amirhalid_ung@yahoo.com
}

\begin{abstract}
The purposes of this research are: 1) to analyze the labor and land use area in Pohuwato District; 2) to analyze the effect of labor and land area usage on increased rice production in Pohuwato; 3 ) to analyze the factors of soil processing technology that have influence on rice production in Pohuwato District. The research method is survey method. The data analysis is descriptive analysis and multiple linear regression analysis. The results showed that the labor use in family and land are has a significant effect on rice production in Pohuwato District of Gorontalo. The other side that the technologies increase has no significant effect on rice production in Pohuwato District of Gorontalo. The results that showed insignificant effect because the technology has a good impact in increased production but not factual, so in the future it the need to evaluate in the technology adoption and the role of agricultural extension must be more optimal.
\end{abstract}

Keywords: Labor, Land area, Technology, Rice production

\section{INTRODUCTION}

Agricultural development is need to fulfill the main human needs as food consumption in order to support the various results of industrial processed food to complement the main human needs. Furthermore this is the answer also to the increasing population growth especially in developing countries has a great desire to apply various technologies and innovations in agriculture sub-sector wetlands including in Indonesia.

Gorontalo Province has a large land potential that can be develop into new fields with the potential of natural resources sufficient to serve source of irrigation. Irrigation determines the successes of rice farming activities that ignored in the calculation of production factors. From the 5 districts in Gorontalo, Pohuwato is the one of the district that widely potential of land that can be develop into the most widespread new rice field with the support of water resources is very adequate. In general, the amount of rice field in Pohuwato reach by 3,751 ha and currently increased to 6,491 ha in addition based on the rice field program from 2011 to 2016. Rice farming in Pohuwato supported continuously by the government since 2011 until now, in 2011150 ha of rice field was introduced, and in 2013 increased to 300 ha, in 2014, 290 ha and by 2016 reach 2,000 ha, the new area of rice field in Pohuwato until 2016 reached 2,740 ha (Agriculture Government Office, 2017).

The new rice field-developing program in Pohuwato has been successful in supporting increased rice production. This found from the increase of rice production that come from the addition of planted area which is sourced from the printing of rice field, where in 2011 the amount of rice production reached 38,241 tons, continuously 
increased to 44,720.63 tons in 2012 ( $16.94 \%), 45,461$ tons in $2013(1.63 \%), 45,658.44$ tons in $2014(0.43 \%)$ and 45,850.03 tons in $2015(0.42 \%)$ (Agriculture Government Office, 2017

Based on data of average rice production in Pohuwato over the last five year, the highest production increase in 2015 compared to several years earlier. One of that, cause of the high increase in production is the exploitation of paddy fields that were carried out in 2012. While the new rice field developing activity conducted in 2016 has not contributed to the increase of rice production in Pohuwato regency, because the rice field has not been utilized optimally because it is still pending completion development of irrigation that is currently implementation (Agriculture Government Office, 2017).

The purposes of this research are to analyze the labor and land use area in Pohuwato District, to analyze the effect of labor and land area usage on increased rice production in Pohuwato, and to analyze the factors of soil processing technology that have influence on rice production in Pohuwato District. Based on this purpose can be explained that labor use in Indonesia divided by two kind. There are labor in family and hired labor. It has a difference count and discussion on this research. The land use also implication to the labor and rice production.

Daniel (2001) described that farming known two kinds of costs, such as cash cost or fees paid and the cost of no cash or fees that are not paid. The fees paid are the costs incurred to pay the wages of hired labor, the cost of purchasing inputs such as seeds, fertilizers, medicines, and bawon harvest. Sometimes it also includes fees for water and irrigation. Cost is a problem for farmers, especially in the procurement of inputs or production facilities. Because of the lack of available costs, farmers often experience losses in their farms. In terms of technical and knowledge, most of our farmers have understood the technological functions they have acquired from several sources, including newspapers, radio, television, counseling, workshops, informal education, leaflets, and or the results of a coffee shop conversation. They have realized the importance of technology, they already need technology, and they are willing to apply the technology, but the constraint is capital.

Soekartawi (2006) described that production is any activity to create add value or add an object to fulfill human needs in their satisfaction. Production not only limited to manufacture, but also to distribution. To adequate perform production activities a producer requires the production factors are managed as effectively and as efficiently as possible so as to provide the best benefits. Theory of Production to see the relation between input (production factor) and output.

Labor is a person who has capability of work performance, within or outside of employment, to produce products of goods or services to meet personal, family, and public needs. Labor is anyone who is capable either of doing work to produce goods or services to meet their own needs or for the community. Manpower is any man or woman who is 15 years old or older who is in and or is going to do work, both inside and outside the working relationship to produce goods or services to meet the needs of society (Mafor, 2015)

Suryana (2001) explained technology is the way in which various natural resources, labor capital and skills are combined to realize the objectives of production. The definition of technology contains a broader dimension and encompasses research, development, production system planning, material supply, information systems, fostering and development of work skills, production equipment and government policies to provide good industrial infrastructure and climates (Suryana, 2000). 
Technology is closely related to the equipment and the ways used in the production process of an industry. Technology can be classified by 3 types are: a) Modern technology or advanced technology; b) Medium technology or precise technology; c) Traditional or low technology

The findings reveal that within the study area: (1) labor intensity is higher and capital intensity is lower than in the major grain-producing and economically developed areas of eastern and central China; (2) the most widely planted crops are those with the lowest labor intensity (oats) and capital intensity (benne); (3) there are marked differences in agricultural land use intensity among households; a major factor affecting land use decision-making is the reduced need for labor intensity for those households with high opportunity costs, such as those with income earned from non-farming activities which alleviates financial constraints and allows for increased capital intensity. As a result, (4) these households invest more in labor-saving inputs, households with a larger number of workers will allocate adequate time to manage their land and thus they will not necessarily invest more in labor-saving inputs. Those households with more land to manage tend to adopt an extensive cultivation strategy. Total income has a positive impact on capital intensity and a negative impact on labor intensity. Households that derive a higher proportion of their total income through farming are more reliant upon agriculture, which necessitates significant labor and yield-increasing inputs. Finally, the authors contend that policy makers should clearly recognize the impacts of non-farming employment on agricultural land use intensity. In order to ensure long-term food security and sustainable agricultural development in China, income streams from both farming and non-farming employment should be balanced (Zhang, 2014).

In this study, an empirical analysis was conducted on the behavior of Japanese rice producers from the standpoint of efficiency in production by using panel data from the Rice Production Cost Statistics by the Ministry of Agriculture, Forestry and Fisheries. The stochastic frontier production function, which comprises four production factors (land, labor, capital stock, and materials), was estimated and the inefficiency indices of production were calculated. Based on this information, the efficient and inefficient rice producers were identified, and the factor demand behavior and characteristics of the arable land utilization for rice production were compared. It was found that inefficient rice producers do not make any adjustments in employment in the short or long run, even if there is a change in the wages. In addition, it was observed that efficient rice producers who hold a large amount of the farms partitioned into small plots reduced the arable land utilization for rice production and increased productivity. However, it was noted that the certified farmers, who should be aiming at an expansion of the scale of operation and efficiency of agricultural operations, tend to reduce arable land utilization for rice cultivation and switch to other crops; moreover, the more efficient the certified farmers are, the larger are the effects of such activities (Kazuo,2017).

How does the amount of land that youth expect to inherit affect their migration and employment decisions? We explore this question in the context of rural Ethiopia using a 2014 cross-sectional dataset indicating whether youth household members from a previous 2010 survey had migrated by 2014, and in which sector they worked in 2014 . We estimate a household fixed effects model and exploit exogenous variation in the timing of land redistributions to overcome endogenous household decisions about how much land to bequeath to descendants. We find that larger expected land inheritances significantly lower the likelihood of long-distance permanent migration and of 
permanent migration to urban areas. Inheriting more land also leads to a significantly higher likelihood of employment in agriculture and a lower likelihood of employment in the non-agricultural sector. Conversely, the decision to attend school is unaffected. These results appear to be most heavily driven by males and by the older half of our youth sample. We also find suggestive evidence that several mediating factors matter. Land inheritance is a much stronger predictor of rural-to-urban permanent migration and non-agricultural-sector employment in areas with less vibrant land markets, in relatively remote areas (those far from major urban centers), and in areas with lower soil quality. Overall, these results affirm the importance of push factors in dictating occupation and migration decisions in Ethiopia (Kosec, 2017).

Base of the three previous researches, found the similarity where the labor use in household will minimize the cost of farming and the efficient of land use will make the efficient rice production.

\section{RESEARCH METHOD}

This research conducted in Pohuwato District, Gorontalo Province. The research time start from September to October 2017. The location of this study was chosen because in general the farmers of the location mostly farming paddy fields in Pohuwato regency.

Research was designed as a survey study. The data used in research that is primary data and secondary data. Primary data were obtained from interviews and fusion dried by farmers of rice field farmers respondents in Pohuwato District. Secondary data is obtained from official reports from relevant agencies in this case such as Gorontalo Central Bureau of Statistics (BPS), and other agencies that can assist in providing data.

After that the population in this study selected several sub-districts is Popayato Sub District, Taluditi Sub District, Randangan Sub District, Buntulia Sub District and Duhiadaa Sub District in Pohuwat, determined by purposive sampling technique or intentionally because the five sub-districts had conducted initial survey so it was feasible to be designated as research area. The total population in the five districts is 2,208 peoples.

This research done by random sampling with total population reached 2.208 rice farmers. One way to get a representative sample is by a process called random sampling. In this process, each member of the population has the same opportunity or opportunity to be elected as samples (Spiegel and Stephens, 2004). The large sample taken by Slovin proposed a formula for determining the size of the sample, thus samples taken as many as 93 respondents from 2,208 people who farm rice paddies.

The data analysis method used in this research is descriptive analysis. The explain is about land use and labor in Pohuwat. This method will provide an explanation or description of various matters relating to the study of data on research, the formula used as follows:

$$
\begin{aligned}
& \mathrm{P}=\frac{f}{\mathrm{n}} \times 100 \% \\
& \text { Where: } \\
& \mathrm{P} \quad=\text { Percentage } \\
& f \quad=\text { Respondent answer frequently } \\
& \mathrm{n} \quad=\text { Respondent total }
\end{aligned}
$$

As phenomena, the data tool measured used is Likert Scale, in Sugiyono (2014). Likert scale is used to measure attitudes, opinions and perceptions of a person or a 
group of social phenomena, In Likert scale the variable to be measured is translated into indicator variables, then the indicator is used as a starting point to arrange the items of instruments that can be questions or statements,

In this study the authors use 5 levels $(1,2,3,4,5)$ by using scores on each index. The percentage score obtained by each indicator shows the system of tertiary irrigation aid implementation to the increase of paddy rice production in Pohuwato by Subagio classification (in MoNE, 2008) as in the following table:

Table 1. Classification score percentage of land use and labor on rice farming

\begin{tabular}{ccc}
\hline Number & Percentage of Score (\%) & Classification \\
\hline 1 & $85-100$ & Very Good \\
2 & $76-84$ & Good \\
3 & $56-75$ & Fair \\
4 & $40-55$ & Poorly \\
5 & $0-39$ & Bad \\
\hline
\end{tabular}

Furthermore, for the identification of problem 2, it was analyzed by using multiple linear regression analysis to know the influence of labor usage and land area of paddy rice production. With the following formula:

$\mathbf{Y}=\mathbf{a}+\mathbf{b}_{1} \mathbf{X}_{1}+\mathbf{b}_{2} \mathbf{X}_{2}+\mathbf{b}_{3} \mathbf{X}_{3}+\mathbf{D}$

Where:

$$
\begin{aligned}
& \mathrm{Y} \quad=\text { Rice production } \\
& A \quad=\text { Constant value } \\
& \mathrm{b} \quad=\text { Regression coefficient } \\
& \mathrm{X}_{1} \quad=\text { Labor use in family } \\
& \mathrm{X}_{2}=\text { Hired labor } \\
& \mathrm{X}_{3}=\text { Land area } \\
& D \quad=\text { Dummy technology }\left(\mathrm{D}_{\mathrm{JI}}=1, \text { Modern; } \mathrm{D}_{\mathrm{JI}}=0, \text { Traditional }\right) .
\end{aligned}
$$

\section{RESULT AND DISCUSSION}

\section{The use of labor and land area}

Based on labor and land area scored includes labor in the family, hired labor and land area. The result of labor and land area of farmers with the highest value of each aspect applied in the farmers can be known results of recapitulation of farmers. The results can be seen in the following table:

Table 2. Labor use and land area recapitulation in Pohuwato District, 2017

\begin{tabular}{lccc}
\hline Indicator & Score & Percentage (\%) & Category \\
\hline Labor use in family & 4.995 & 71.61 & Very Good \\
Hired labor & 5.691 & 81.59 & Good \\
Land area & 5.864 & 84.07 & Good \\
\hline Total & $\mathbf{1 5 . 9 9 4}$ & $\mathbf{7 9 . 0 9}$ & Good \\
\hline
\end{tabular}

Through the total recapitulation scored above, showed that the use of labor and land area has been seen from each aspect such as labor in the family, hired labor and land area that has been successfully applied by the farmer group in order to increase productivity of rice field. Through total score percentage of respondents answers can be seen that the participation of farmers in the use of labor and land area has been done by the farmers. Furthermore, it can be seen that the aspect of labor activities in the family by the farmers in the category is quite good. It means that the farmers are able to 
provide decisions in conducting the activities of the use of labor in the family because they realize that the participation rate of farmers is one of the most important aspects and the first to do in the farming. Based on the percentage of total score respondents answers seen that the activities of hired labor by farmers included in either category. This means that farmers or respondents have a very good awareness of the activities of hired labor of farmers to productivity of rice paddy fields such as in the processing of land, planting simultaneously and plant maintenance activities such as eradication of pests and diseases of plants until harvest.

Based on the percentage of total score respondents answers seen that the size of the land area included in either category. Furthermore, based on the total score of respondents answers to the activities of the area of land own, the area of land rent and the amount of rent is in the category of good, which means that in doing the third indicator farmers have been good in terms of doing so from processing to harvesting. So overall, this farmer has been very good in the use of labor and land area in Pohuwato.

\section{Classical assumption test}

\section{Normality test}

The residual normality test purpose to test whether in the regression model, the dependent variable and the independent variable have a normal distribution or not. A good regression model is to have a normal or near normal residual distribution. The Normality Test can also be identified by the Normal Probability Plot method that compares the cumulative distribution of the actual data with the cumulative distribution of the normal distribution. Normal probability results the plot is presented in Figure 1 below:

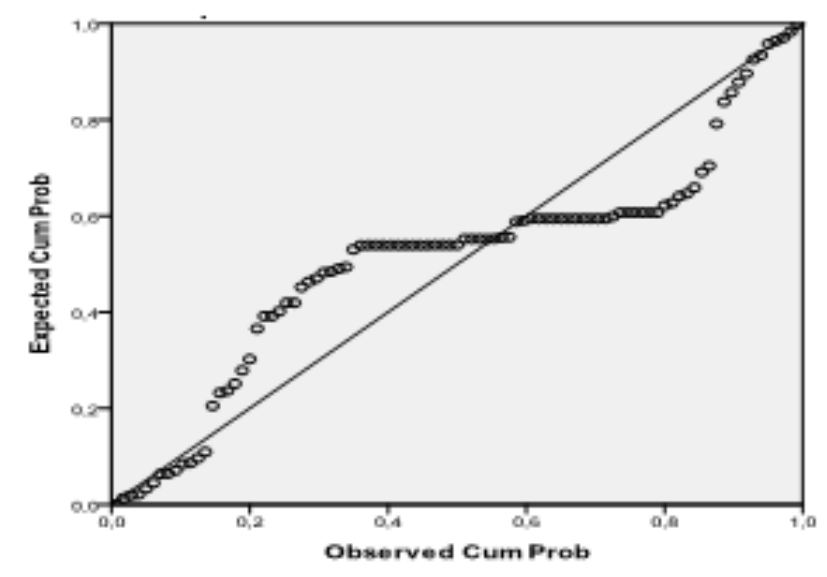

Figure 1. Result of normality probability plot

Based on figure 1 showed that the data (point) spreads around the diagonal line and follows the direction of the diagonal line. By following the basic decision-making above, it is concluded that the data in this regression model meets the assumption of data normality. It can be seen that there are some data distribution points that are slightly off the mark, so the need to continue with Kolmogorov Smirnov test.

Kolmogorov Smirnov is a normality test performed on residual regression testing (Sudjana, 2002). In order to know whether or not the normal distribution of variables in this study was conducted by non-parametric statistical test KolmogorovSmirnov (K-S Test). If the Kolmogorov-Smirnov significance value is greater than the alpha value (0.05), then the data follows a normal distribution. One Sample test results Kolmogorov Smirnov can be seen in table 3 below: 
Table 3. One-Sample Kolmogorov-Smirnov Test

\begin{tabular}{|c|c|c|}
\hline & & $\begin{array}{l}\text { Unstandardiz } \\
\text { ed Residual }\end{array}$ \\
\hline$N$ & & 93 \\
\hline \multirow[t]{2}{*}{ Normal Parameters ${ }^{a, b}$} & Mean &, 0000000 \\
\hline & Std. Deviation & 5,17191708 \\
\hline \multirow[t]{3}{*}{ Most Extreme Differences } & Absolute & .163 \\
\hline & Positive &, 162 \\
\hline & Negative &,- 163 \\
\hline Kolmogorov-Smirnov Z & & 1,575 \\
\hline Asymp. Sig. (2-tailed) & & .014 \\
\hline
\end{tabular}

Based on the above table can be seen that the test of data normality (Kolomogorov Smirnov) found that the value Kolomogorov Smirnov (KS) of residual regression that is equal to 1.575. The value is smaller than the value of $Z$ table (1.96). Therefore, it can proof that the data in this study has a normal distributed value.

\section{Multicollinearity test}

Multicollinearity test is purpose to determine the existence of a definite linear relationship between some or all of the independent variables describing the regression model. A good regression model should not be correlated between independent variables.

To know the presence of multicollinearity can also be seen on Tolerance and VIF (Variance Inflation Factor) value, that is: if tolerance value $>0.10$ and VIF $<10$, hence can be interpreted that there is no multicollinearity in the research. If tolerance values $<0.10$ and $\mathrm{VIF}>10$, then it can be interpreted that there is interference multicollinearity in this research.

Table 4. Multicollinearity result

\begin{tabular}{lcc}
\hline Variable & VIF & Result \\
\hline Labor use in family & 2.591 & Non Multicollinearity \\
Hired labor & 1.810 & Non Multicollinearity \\
Land area & 2.654 & Non Multicollinearity \\
Dummy & 1.024 & Non Multicollinearity \\
\hline
\end{tabular}

Based on Table 4, showed that there is no multicollinearity regression model because VIF independent variable $<10$, that is variable of labor in family equal to 2,591, hired labor variable equal to 1,810, variable of land area equal to 2,654 and technology equal to 1,024 , so in this research no multicollinearity in regression.

\section{Heteroscedasticity test}

Figure 2 is the result of data that process (Scatterplot) of heteroscedasticity test below: 


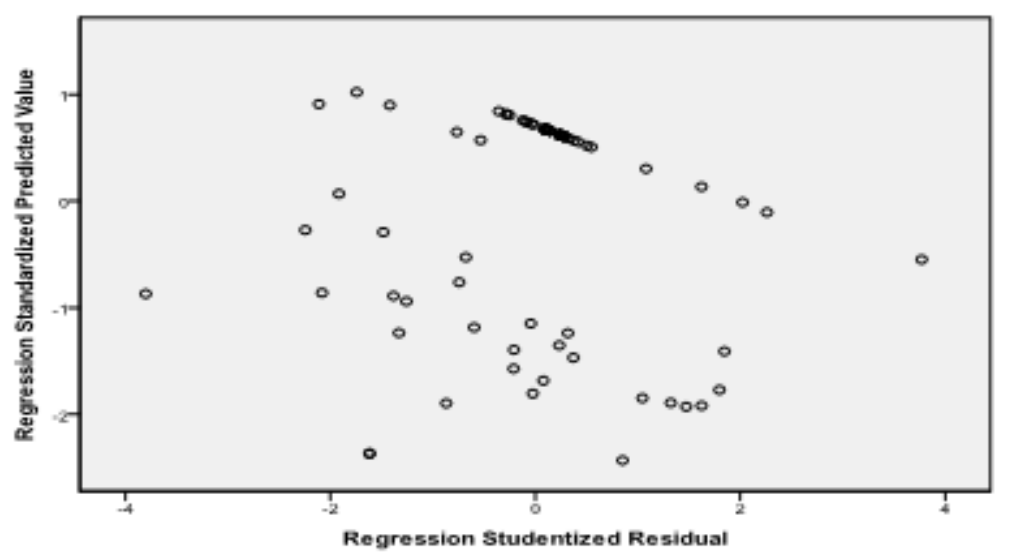

Figure 2. Heteroscedasticity test result

Based on the picture above showed that (1) the points spread randomly and (2) spread both above and below the zero on the $\mathrm{Y}$ axis. Therefore it can be concluded that there is no heteroscedasticity in the regression model data.

\section{Regression analysis}

$\mathrm{R}^{2}$ Test is used to know the influence of dependent and independent variable in this research from the total of influence of labor in family, hired labor, land area and technology to rice production in Pohuwato, Gorontalo Province known from result of coefficient of determination $\left(\mathrm{R}^{2}\right)$ below:

Table 5. Coefficient of determination test result $\left(\mathrm{R}^{2}\right)$

\begin{tabular}{lcccc}
\hline Model & R & R Square & Adjusted R Square & $\begin{array}{c}\text { Std. Error of the } \\
\text { Estimate }\end{array}$ \\
\hline 1 & $.937^{\text {a }}$ & .878 & .872 & 5.35095 \\
\hline
\end{tabular}

a. Predictors: (Constant), D, X3, X2, X1

b. Dependent Variable: $Y$

Based on the Table 5, the value of determination coefficient adjusted $\mathrm{R}$ of 0.872 . Means that $87.2 \%$ of the rice production in Pohuwato, Gorontalo Province can be explained by the labor in the family, hired labor, land area, and technology adoption in Pohuwato District, Gorontalo Province. While $12.8 \%$ is explained by other factors outside the model. Other factors outside the production function model that are also suspected to have an impact on rice production are the fertility of the land and the influence of climate and weather and the intensity of pests and diseases.

Simultaneous (F test) between independent variables in this research between the labor in the family (X1), hired labor (X2), land area (X3), technology (D) and paddy rice production $(\mathrm{Y})$. Results of the analysis together obtained the results below:

Table 6. Simultaneous test (F test)

\begin{tabular}{llrrrrr}
\hline Model & & $\begin{array}{c}\text { Sum of } \\
\text { Squares }\end{array}$ & df & Mean Square & F & \multicolumn{1}{c}{ Sig. } \\
\hline 1 & Regression & 18084.596 & 4 & 4521.149 & 157.902 & $.000^{6}$ \\
& Residual & 2519.677 & 88 & 28.633 & & \\
& Total & 20604.272 & 92 & & & \\
\hline
\end{tabular}


Based on the result of analysis in Table 6 obtained value of F Test is 157.902 with probability value 0.000 , because the probability value is smaller than 0.05 then the value of Fhitung obtained is significant. So it can be said that there is a positive and significant influence between labor in the family (X1), hired labor (X2), land area (X3) and technology (D) together to paddy rice production (Y).

$\mathrm{T}$ - Test or regression coefficient partially used to determine whether the partially independent variables significantly affect or not to the dependent variable. In this research partial test is used to know how far labor in family (X1), hired labor (X2), land area (X3) and technology (D) partially influence to paddy production (Y), as for the results of partial analysis can be seen in the table below:

Table 7. Regression analysis model

\begin{tabular}{llrrrrr}
\hline & & \multicolumn{2}{c}{$\begin{array}{c}\text { Unstandardized } \\
\text { Coefficients }\end{array}$} & $\begin{array}{c}\text { Standardized } \\
\text { Coefficients }\end{array}$ & & \\
\cline { 3 - 5 } Model & & \multicolumn{1}{c}{ B } & Std. Error & Beta & \multicolumn{1}{c}{ T } & Sig. \\
\hline 1 & (Constant) & -10.235 & 3.394 & & -3.016 & .003 \\
& X1 & .156 & .121 & .078 & 1.292 & .200 \\
& X2 & .367 & .071 & .258 & 5.149 & .000 \\
& X3 & 1.048 & .092 & .689 & 11.348 & .000 \\
& D & .174 & 1.224 & .005 & .142 & .887 \\
\hline
\end{tabular}

Based on the result from the previous study we can compare that, there is a significant influence between the labor from household and hired labor. Where if the farmers use the household labor, the can reach the labor saving for the cost of farming input. The household labor could have an allocate adequate time to manage their land and they can have more cultivation strategy (Zhang, 2014). It could develop the efficient farming production. From this previous research, there are the discussions about this research result below:

\section{The effect of labor in the family on rice production}

Based on a positive analysis of elasticity of production indicates that labor in the rice farming family is in a rational area. Based on the value of t-test is obtained input production of labor in the family of 1.292 which value of the significance of labor in family $(0.200)$ higher than probability value 0.05 . So it can be concluded that labor in the family has no significant effect on rice production in Pohuwato, Gorontalo Province.

\section{The influence of hired labor on rice production}

Based on the analysis showed a positive elasticity of production indicates that the hired labor rice farming is in the rational area. Then based on t-test value obtained input production hired labor of 5.149 which value significance of hired labor $(0.000)$ smaller than probability value 0,05 So it can be concluded that hired labor have a significant effect on rice production in Pohuwato, Gorontalo Province.

Regression coefficient $X 10,156(\beta 1=0,156)$. The regression coefficient variable of labor in family showed that every change of labor in the family is 1 unit of rice production in Pohuwato, Gorontalo Province will change of 0.156 units with the condition of variable hired labor, land area and technology (dummy) in a constant state (cateris paribus).

\section{The influence of land area on rice production}

Based on the analysis showed a positive elasticity of production indicates that the area of rice cultivation area is in a rational area. However, based on t-test value obtained input production land area of 11,348 which significance value land area 
(0.000) smaller than probability value 0,05 . So it can be concluded that the Land Area has significant effect on rice production in Pohuwato, Gorontalo Province.

Regression coefficient of X3 $1,048(\beta 3=1,048)$. The regression coefficient of the land area showed that every change in the variable of land area by 1 unit, then the rice production in Pohuwato, Gorontalo Province will change by 1,048 units with the variable of labor in family, hired labor and technology (dummy) in constant condition (cateris paribus)

\section{The effect of technology on rice production}

Based on the analysis showed a positive production elasticity indicates that rice cultivation technology is in a rational area because the use of technology can increase rice production. Then based on the value of t-test obtained input technology production of 0.142 which value of technology significance $(0.887)$ higher than probability value 0.05 . So it can be concluded that the technology has no significant effect on rice production in Pohuwato, Gorontalo Province.

\section{CONCLUSIONS AND RECOMMENDATIONS}

\section{Conclusions}

The use of labor and land area from the result of the percentage of total score of respondents' answers on labor indicators in the family of $66 \%$ included in the category is good enough, on the indicator of hired labor by $81 \%$ included in both categories, and on the indicator of land area of $83 \%$ included in either category. So that the use of labor and land area in the research location is good use.

The labor and land area use on rice farming simultaneously have a positive and real effect on rice production. While the partial that have a positive and real effect on wetland paddy production is the hired labor, and the land area.

\section{Recommendations}

There is need to be a training and mentoring program available in Pohuwato District in order to improve the labor to develop farmers welfare. We recommend that more farmers use modern technology to further increase rice production in Pohuwato District.

\section{REFERENCES}

Daniel, Moehar. (2001). Pengantar Ekonomi Pertanian. PT Bumi Aksara, Jakarta.

Kazuo, Ogawa. (2017). Inefficiency in Rice Production and Land use: A Panel Study of Japanese Rice Farmers. RIETI Discussion Paper Series 17-E-020 March 2017. Osaka University

Kosek, Katrina. Ghebu, Hosaena, Holtemeyer, brian, Mueller, Valerie, Schmidt, Emily. (2018). The Effect of Land Access on Youth Employement and Migration Decisions: Evidence From Rural Ethiopia. American Journal of Agricultural Economics, Volume 100, Issue 3, 1 April 2018; 931-954, https://doi.org/10.1093/ajae/aax087

Mafor, Klifensi Ilona. (2015). Analisis Faktor Produksi Padi Sawah Di Desa Tompasobaru Dua Kecamatan Tompasobaru. Jurnal. Fakultas PertanianUniversitas Sam Ratulangi, Manado.

Soekartawi. (2006). Analisis Usahatani. Penerbit Universitas Indonesia, Jakarta.

Soekirno Hardjodinomo, (1987). Bertanam Padi. Bandung: Binacipta.

Sudjana, (2002), Metoda Statistika, Penerbit PT Tarsito, Bandung

Sugiyono. (2014). Statistika Untuk Penelitian. Alfabeta 
Suryana, Achmad dan Sudi Mardiyanto. (2001), Bunga Rampai Ekonomi, LPEM FEUI : Jakarta

Zhang, Huiyuan, Hao, Haiguang, Li, Xiubin, tan, Minghong, Zhang, Jiping. (2015). Agricultural Land Use Intensity and It is Determinants: A Case Study in Taibus Banner, Inner, Mongolia, China. Frontiers of Earth Science June, 2015. Vol. 9 pp 308-318 